\title{
The extent and impacts of ungulate translocations: South Africa in a global context
}

\author{
Dian Spear", Steven L. Chown \\ DST-NRF Centre of Excellence for Invasion Biology, Department of Botany and Zoology, Stellenbosch University, \\ Private Bag X1, Matieland 7602, South Africa
}

\section{A R T I C L E I N F O}

Article history:

Received 28 May 2008

Received in revised form

12 September 2008

Accepted 17 October 2008

Available online 6 December 2008

\section{Keywords:}

Mammals

Propagule pressure

Range change

Translocation

\begin{abstract}
A B S T R A C T
Despite the apparent risks of the introduction of non-indigenous ungulates to biodiversity, relatively little is known globally about the pathways of introduction, propagule pressure and realized impacts of ungulate introductions. These issues were examined here by investigating ungulate introductions to South Africa within a global context. Across countries globally, introduced ungulate richness is not related to indigenous ungulate richness, and several countries are clear outliers. South Africa is second only to the USA in the number of ungulate species introduced to date. Zoos have traded more ungulate species and individuals to non-zoo recipients than to other zoos, highlighting the tensions that exist between in situ and ex situ conservation goals. Introductions to, and extralimital introductions within South Africa have increased through time, with propagule pressure being highest in areas with high human population density. The long distances ungulates have been translocated raise concerns for genetic homogenization. Translocations of indigenous ungulate species extralimitally have significantly altered range sizes, typically to a greater extent than is expected from range shifts associated with global climate change. Although ungulate introductions and translocations are likely to have impacts on biodiversity, evidence for such impacts in South Africa, and elsewhere, is limited. Whilst arguments may be made for a precautionary approach to ungulate introductions, an evidence-based one is much more likely to deliver efficient and convincing conservation decision-making.
\end{abstract}

(c) 2008 Elsevier Ltd. All rights reserved.

\section{Introduction}

Non-indigenous ungulate species are thought to pose a threat to biodiversity. They might hybridise with indigenous ungulates (Goodman et al., 1999), compete with several taxa (Baccus et al., 1985; Côté, 2005), host foreign pathogens and parasites (Meltzer, 1993; Cunningham, 1996) and alter ecosystem functioning (Wardle et al., 2001; Bayne et al., 2004). By contrast, the ecological benefits of translocations include reintroductions and restocking (Griffith et al., 1989), enhancement of genetic diversity of inbred populations (Moritz, 1999; Storfer, 1999), restoration of ecosystem function by the controversial process of 're-wilding' (Donlan, 2005; Zimov, 2005; Rubenstein et al., 2006), and assisted migration to mitigate climate change (Hoegh-Guldeberg et al., 2008). Likewise, substantial economic benefits from ungulate introductions have also been realized (e.g. from hunting Hofer, 2002; Loveridge et al., 2006).

Despite introduced ungulates having both costs and benefits, and being counted among the most invasive species globally (Lowe et al., 2000), little research has been done in the last two decades to quantify introduction and translocation patterns and impacts. Indeed, over this period, only c. 50 readily accessible studies have been published in the Anglophone

* Corresponding author: Tel.: +27 21808 3585; fax: +27 218082995.

E-mail addresses: dspear@sun.ac.za (D. Spear), slchown@sun.ac.za (S.L. Chown). 0006-3207/\$ - see front matter @ $\odot 2008$ Elsevier Ltd. All rights reserved. doi:10.1016/j.biocon.2008.10.031 
literature on the realized effects of ungulate introductions, most of which concern impacts on vegetation (see supplementary methods and results in the electronic Supplementary material). Furthermore, little information exists on propagule pressure (frequency and number of individuals introduced) (though see Forsyth and Duncan, 2001; Forsyth et al., 2004), the pathways of ungulate introductions (though see Lever, 1985; Long, 2003), and the extent to which plausible conservation concerns are being realized (though see Dolman and Wäber, 2008). This general scarcity of information is true also for those countries, such as the United States (Butler et al., 2005), and South Africa, that have substantial numbers of introduced ungulates and active translocation programmes.

Although South Africa is rich in indigenous ungulates (Skinner and Chimimba, 2005), it has a substantial history of ungulate introductions, and extralimital translocations of indigenous ungulates (e.g. Lloyd and Millar, 1983; Brooke et al., 1986), often for financial reasons (Castley et al., 2001; Lindsey et al., 2006). Nonetheless, concerns have frequently been raised about the potential conservation implications of these actions (e.g. Brooke et al., 1986; Bothma, 2005). Indeed, laws to regulate the translocation and introduction of large mammals have recently been enacted (National Environmental Management: Biodiversity Act: Anon., 2004). However, the game and hunting industries have questioned these regulations and are of opinion that evidence for the negative impacts of non-indigenous ungulates in South Africa is limited (S.L.C. personal observations at Ministerial Stakeholder meeting, February 2007). For this reason, and because of relatively accessible information on introductions and translocations (e.g. Penzhorn, 1971), South Africa makes an excellent case study for quantifying the extent of ungulate translocations and introductions, investigating the pathways involved, and determining the extent to which proposed conservation problems associated with introductions have been realized.

Therefore, the aim of this study is to address these questions using the South African situation as an exemplar. To do so we adopt several approaches. First, to assess the extent of introductions in South Africa relative to the global situation, and the extent to which species introductions are influenced by indigenous species richness (the rich get richer hypothesis - see Stohlgren et al., 1999), we examine the relationship globally between numbers of indigenous and introduced ungulates within countries. Next, we investigate temporal trends in ungulate introductions into the country to determine whether rates of introduction and translocation are increasing, whether zoos might serve as a pathway for introductions, and the distances over which ungulate translocations have taken place. To determine the extent to which proposed impacts have been realized by these introductions, we assess documented, rather than hypothesized, impacts of ungulate introductions in South Africa, and the extent of change in geographic range size that has been a consequence of translocations. The latter is especially significant given that much emphasis, both in South Africa (Erasmus et al., 2002) and globally (Thomas et al., 2004; Parmesan, 2006), has been placed on climate change-effected alterations of geographic range size. However, for widely traded species, range alterations through direct human actions may be as extensive as those that are predicted to be caused by climate change. Finally, areas of potential conservation concern are identified based on high levels of introduction activity and potential impacts.

\section{Methods}

This study focuses on the orders Artiodactyla and Perissodactyla (following Wilson and Reeder, 2005). Although this is a polyphyletic grouping (e.g. Bininda-Emonds et al., 2007) it is useful because the ungulates are typically considered distinct from other taxa, especially by the hunting industry, which is responsible for many translocations (Castley et al., 2001; Long, 2003).

\subsection{Ungulate introductions globally}

To determine whether indigenous ungulate species richness plays a role in the numbers of ungulate introductions, indigenous ungulate species richness data were obtained for countries globally from Wilson and Reeder (2005), and for introduced ungulates from Siegfried (1962), Lloyd and Millar (1983), Lever (1985), Brooke et al. (1986), Mungall and Sheffield (1994), Castley et al. (2001), Forsyth and Duncan (2001), Hofer (2002), Long (2003), Dryden and Craig-Smith (2004), Forsyth et al. (2004), and Wilson and Reeder (2005). These data were supplemented with data collected from internet searches for non-indigenous ungulate species offered for hunting in countries globally, using country and species names as search terms in Google ${ }^{\mathrm{m}}$. We recognize that the absence of a listing in any one of the above publications or on the internet does not necessarily mean the species is absent from a country. However, in keeping with many macroecological studies we assume that absence data reflect real absences (the problems with this assumption and the need for making it have been widely discussed, see e.g. Gaston and Blackburn, 1999; Rondinini et al., 2006). The relationship between the number of introductions and indigenous ungulate species richness for countries globally was assessed using a generalized linear model (Poisson distribution, log-link function), corrected for over-dispersion, implemented in Statistica 8.0 (StatSoft, Tulsa, Oklahoma).

\subsection{Zoos as a pathway of ungulate introductions in South Africa}

The transfer of non-indigenous species from zoos has been recorded as a route for ungulate introductions in various countries in the past (Lever, 1985; Long, 2003; Hulme et al., 2008), and it appears that this phenomenon may be more widespread than previously appreciated (Spear and Chown, 2008). To investigate the role of zoos as a pathway for or source of ungulate introductions in South Africa, zoo transfer reports from the International Species Information System (ISIS) (ISIS, 2007) were searched for non-indigenous ungulates that were sold or traded by South African zoological institutions. The number of non-indigenous ungulate species and individuals that were sold or traded from zoos in South Africa to other zoos, and to non-zoo recipients, were summed for each year from 1987 to 2006. A Mann-Whitney U test was 
used to determine whether significantly more non-indigenous ungulates were transferred from zoos to other zoos, or to elsewhere between 1987 and 2006.

\subsection{Trends in ungulate introductions in South Africa}

To investigate temporal trends in ungulate introductions in South Africa, data were compiled at a quarter-degree grid-cell (QDGC) resolution for indigenous species from Keith (2004) and for extraregional (species from outside South Africa) and extralimital (indigenous species outside their historical extent-of-occurence) ungulates from advertisements in Landbou Weekblad (Agriculture Weekly) magazine for all issues from 1965 to 2005 following the methods outlined in Spear and Chown (2008).

New advertisements of extraregional species, extralimital species, and genetic variants and hybrids were summed, for each QDGC, for each year. Spearman's rank correlations were used to assess the relationship between the number of introductions and time. Temporal autocorrelation in the data was tested for by constructing correlograms using the autocorrelation function of time series analysis in Statistica 8.0 (StatSoft, Tulsa, Oklahoma). The statistical significance of temporal autocorrelation at $p<0.05$ was tested for using the method of Oden (1984). Significant temporal autocorrelation was found in the extralimital and variant advertisement data. To assess the effect of temporal autocorrelation in the data the proportion of the data required to retain statistical significance was calculated. Due to the variation in range size (extent-of-occurrence) of ungulate species in South Africa, the area available for extralimital introductions in the country differs for each species, making direct comparisons of the number of extralimital introductions for each species inappropriate. As an alternative to direct comparisons of extralimital introductions a value of preference for extralimital introduction was calculated for each species. Preference values were calculated as the number of QDGCs where the species has been advertised extralimitally divided by the number of QDGCs available for extralimital introduction for each species.

\subsection{Translocation distance}

To determine the distances ungulates have been translocated in South Africa, two independent data sets were assessed. Penzhorn (1971) documented the re-introduction of ungulates into South African National Parks up to 31st December 1970. The coordinates of the National Parks and towns mentioned in the paper were used to estimate Euclidean distances of translocation using Shirokov's spherical law of cosines (Dale, 2005). Second, permit application data were obtained from CapeNature (Western Cape (provincial) nature conservation). The permit applications were for the translocation of ungulates into, within, and out of the Western Cape, South Africa, between March 2000 and August 2006. These data provide both the origin and destination municipality of the individual(s) to be translocated, so enabling the calculation of translocation distances and the construction of a dispersal kernel for the translocated species. The centroids of municipal districts were used to estimate the
Euclidean distance of each translocation as above. Data from the eight other provincial authorities in South Africa were not readily accessible.

\subsection{Extent of range change}

Methods for calculating range size and changes in range size have long been discussed (e.g. area-of-occupancy and extent-of-occurrence (EOO) - see Gaston, 1990; and the biases of minimum convex polygons - see Burgman and Fox, 2003). Moreover, to compare the results from this study with published information on range change as a result of climate change, a method comparable to that used in climate-induced range change modelling was required. For example Erasmus et al. (2002) calculated range size as the number of QDGCs suitable for occupation by a species in South Africa before and after predicted climate change (modelled using species presence data and climate data). Bearing these factors in mind, as well as data availability, the extents of range change as a result of translocations were calculated using four different methods. An example of data used to calculate range change can be seen in Fig. 1 in the electronic Supplementary Material.

For method one, maps from Skinner and Chimimba (2005) were used to determine the full (Africa-wide) historical EOO of the indigenous ungulate species, and extralimital advertisement data from Landbou Weekblad were then used to calculate the extended EOO as minimum convex polygons. The distribution maps from Skinner and Chimimba (2005) were digitised using Landserf 2.2 (www.landserf.org) and converted into ArcGIS shape files using Gen2Shp (Wagner, 2002). The areas of each EOO were calculated in ArcMap 9.1 (ESRI, Redlands, California). Minimum convex polygons (MCPs) were created using the central points of QDGCs with extralimital advertisement data from Landbou Weekblad and the minimum convex polygon tool from Hawth tools (Beyer, 2004). Extended EOOs were taken as the area between the boundary of the historical EOO and the extreme boundary of the MCP, clipping the MCP to the boundaries of South Africa. Change in distribution was calculated as a percentage increase in the EOO for each species.

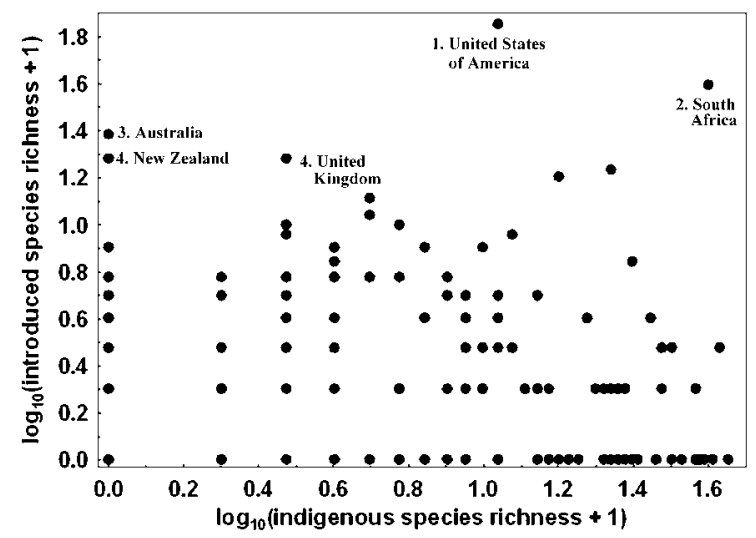

Fig. 1 - Non-indigenous ungulate introductions for countries globally in relation to the indigenous ungulate speciesrichness of each country. 
The remaining three methods used Keith (2004) as a source of historical distribution data. Keith's (2004) data only provides distribution ranges (as EOO and presence in QDGCs QDGC EOO) for South Africa, and not for the complete ranges of the species concerned. For method two, the number of QDGCs for each species in South Africa was counted, and the number of QDGCs with advertisement data was used to calculate the extended QDGC EOO. For method three the historical EOO was calculated as a MCP using the central point of QDGCs in the QDGC data and the extended EOO was calculated using MCPs including Landbou Weekblad advertisement data. Lastly, for method four the historical and extended EOOs of the ungulate species were calculated with Alpha hulls $(\alpha=2)$ (Mandal and Murthy, 1997) using the QDGC data from Keith (2004) and the Landbou Weekblad advertisement data. Alpha hulls were calculated using a customized program written in Mathematica 6.0 (Wolfram Research, Inc., Champaign, Illinois). Wilcoxon matched pairs tests (Conover, 1999) were used to compare the extent-of-occurrence before and after distribution changes as a result of translocations in all cases.

\subsection{Impacts of ungulate introductions and areas of conservation concern}

To assess documented, rather than hypothesized, impacts of ungulate introductions in South Africa, the literature was thoroughly examined for work concerning such impacts (see supplementary methods in the electronic Supplementary material). The impacts documented and the nature of the evidence provided was then recorded (for a similar approach see Parr and Chown, 2003).

Due to concerns about potential ecological impacts (e.g. introgression, competition, see Section 1), introductions of extraregional, extralimital, genetic variant, and hybrid ungulates in South Africa were designated here to constitute evidence of a potential conservation concern. Other forms of conservation threat included propagule pressure (see Lockwood et al., 2005 for discussion) and the introduction of non-indigenous species that can hybridise with indigenous species. For this analysis, Keith (2004) was used as a source of historical extent-of-occurrence data.

Propagule pressure was calculated by summing extralimital species data for each year (between 1996 and 2005) a species was advertised at a particular location (i.e. a maximum value of 10 for each species). The relationships between propagule pressure and human population size, average annual income, and indigenous ungulate species richness were examined using generalized linear models (Poisson distribution, log-link function) correcting for over-dispersion. The Akaike information criterion was used to select the best model, with Akaike weight used to indicate the likelihood of a model being the best of the full set of models (Johnson and Omland, 2004). It was assumed that propagule pressure might increase with human population density for two major reasons. First, because the probability of survival of the introduced animals is likely higher in favourable (high water and high energy) areas in South Africa (which would also mean higher indigenous ungulate species richness - see Andrews and O'Brien, 2000; Evans et al., 2004 for rationale), and high energy areas support high human population densities (Chown et al., 2003), the two variables might be related. Second, high human population density areas might also have a greater number of land owners able to afford the expense of ungulate purchases, in which case a relationship with average annual income might also be expected. Data to examine these hypotheses were obtained from Statistics South Africa (Statistics South Africa, 1996, 2001).

QDGCs where introduced ungulates had potential to hybridise with indigenous species were identified. Only congeneric hybridisations were considered here, recalling that hybridisations are only problematic when they result in fertile offspring. Seven species pairs were considered, three of which included one extraregional species (see supplementary methods in the electronic Supplementary material for potential hybrid pairs).

\section{Results}

\subsection{Trends, pathways, and translocation distances}

For countries to which ungulates have been introduced, no significant relationship was found between the number of introduced ungulates and indigenous ungulate species richness $\left(\chi^{2}=1.97, p=0.16\right)$. South Africa was found to have introduced the second largest number of non-indigenous ungulates of any country globally, 38 compared to the United States of America's 70 (Fig. 1).

Over the period 1987-2006, a total of 500 individuals of 19 non-indigenous ungulates were reported as sold or traded from zoos in South Africa to non-zoo recipients in South Africa (Fig. 3, no sales in 1987). More ungulate species (adjusted $Z=-3.63, p<0.001$ ) and individuals (adjusted $Z=-4.47$, $p<0.001$ ) were sold to non-zoo recipients than to zoo recipients.

Advertisements were recorded for a total of 385 out of 1816 QDGCs during the period 1965 to 2005 . The number of advertisements for ungulate species increased through time between 1965 and 2005 (Fig. 2; extraregionals: $r_{\mathrm{s}}$ (Spearman's $R)=0.29, p<0.001$, with $34 \%$ of data $p=0.047$; extralimitals:

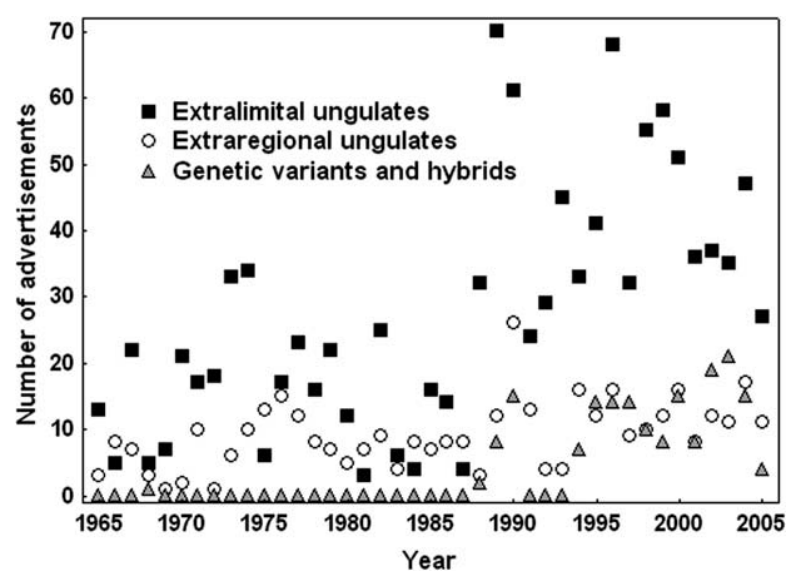

Fig. 2 - Number of new extraregional, extralimital and genetic variant, and hybrid ungulate advertisements per quarter-degree grid-cell in South Africa, 1965-2005. 

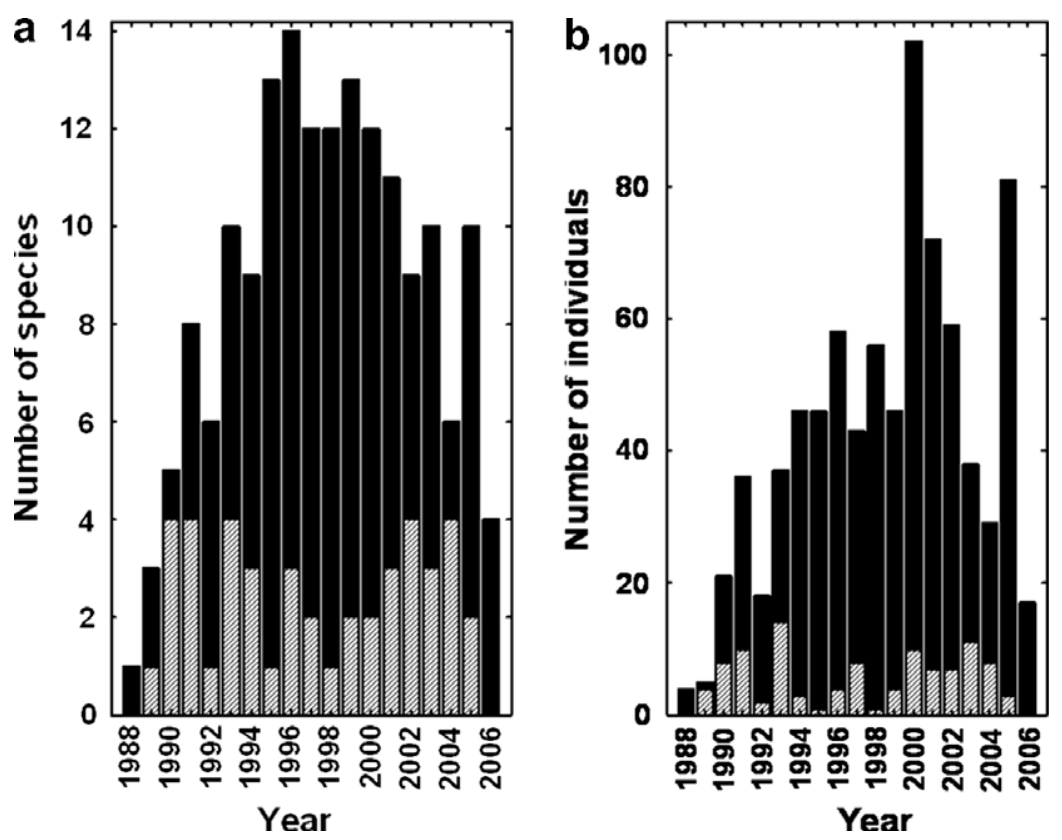

Fig. 3 - The number of non-indigenous ungulates sold or traded from zoos to other zoos (hatched bars) and to non-zoo recipients (solid bars) between 1988 and 2006, (a) number of species and (b) number of individuals.

$r_{\mathrm{s}}=0.43, p<0.001$, with $24 \%$ of data $p=0.039$ and variants: $r_{\mathrm{s}}=0.57, p<0.001$, with $20 \%$ of data $p=0.031$ ). In total, the 18 extraregional ungulates (in 158 QDGCs) constituted $9 \%$ of advertisements. The most widely sold extraregional species were fallow deer (Dama dama) (98 QDGCs), water buffalo (Bubalus bubalis) (51 QDGCs), one-humped camel (Camelus dromedarius) (31 QDGCs), lechwe (Kobus leche) (28 QDGCs), and wild boar (Sus scrofa) (22 QDGCs). All indigenous ungulates were advertised for sale outside as well as inside their historical distribution ranges and accounted for $55 \%$ of advertisements. Extralimital ungulates (in 264 QDGCs) comprised $31 \%$ of advertisements. The most preferred extralimital ungulates advertised were eland (Tragelaphus oryx), gemsbok (Oryx gazella), blesbok (Damaliscus pygarus phillipsi), Burchell's zebra (Equus burchellii), and impala (Aepyceros melampus). A total of 14 different genetic variants and hybrids (in 83 QDGCs) comprised $5 \%$ of advertisements. The most widely sold variants were white blesbok (D. p. phillipsi) (31\%), black springbok (Antidorcas marsupialis) (26\%), and white springbok (A. marsupialis) (17\%).

For the 67 location-pairs from Penzhorn (1971) the mean Euclidean distance of translocation was $483 \pm 287 \mathrm{~km}$. For the 621 location-pairs from the CapeNature data the mean Euclidean distance of translocation was $490 \pm 18 \mathrm{~km}$ (Fig. 4).

\subsection{Extent of range change}

Despite differences in results obtained from using different methods, all methods used indicated that the extent-ofoccurrence differed significantly after the translocation of ungulates outside their historical ranges in South Africa (each comparison gave the same result of: $Z=4.372, p<0.001)$. Method one gave a mean increase in range size of $58 \pm 16 \%$. When only using advertisement data from outside the species EOO the mean increase in range size for method two was
$52 \pm 49 \%$ and when all advertisement data were used, including data from inside the species EOO a mean value of $117 \pm 82 \%$ was obtained. Method three gave a mean increase in range size of $159 \pm 190 \%$ and method four a mean increase in range size of $187 \pm 191 \%$ (Fig. 5).

\subsection{Impacts of ungulate introductions and areas of conservation concern}

Few studies have clearly documented the impacts of ungulate introductions in South Africa. Indeed, only eight studies have been published despite the wide range of impacts that could have been realized, and in several of these the evidence for the impact concerned is not especially strong and might even be considered anecdotal in a few cases (see supplementary results in the electronic Supplementary material).

The best predictive model for propagule pressure included human population density, indigenous ungulate species richness and average annual income, and propagule pressure increased with increasing population density (Table 1). Most of the populated areas of South Africa, where land is privately owned, were categorized as areas of potential conservation concern due to ungulate introductions (Fig. 6). No significant relationships between propagule pressure and indigenous ungulate species richness or average annual income were found (Table 1).

\section{Discussion}

\subsection{Trends and pathways}

Many countries around the world have introduced large numbers of ungulates regardless of indigenous ungulate species richness. According to the available data South Africa has introduced more non-indigenous ungulates than any other 


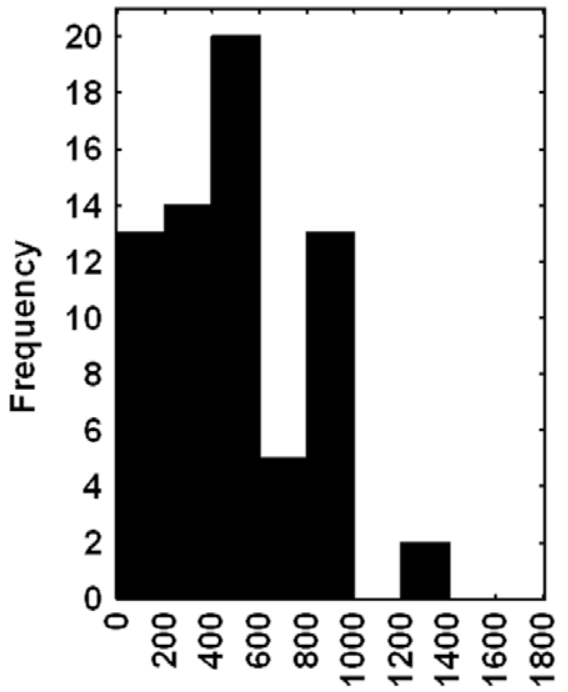

Penzhorn (1971)

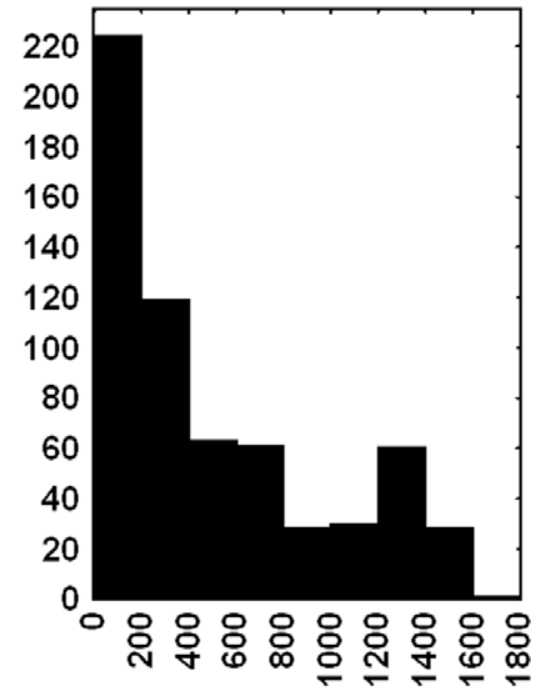

CapeNature (2000-2006)

Euclidean translocation distance $(\mathrm{km})$

Fig. 4 - Frequencies of translocation distances calculated using data from Penzhorn (1971) on the re-introduction of ungulates to National Parks (up to 1970) and translocation permit application data from CapeNature (2000-2006), both excluding translocations from outside the country.
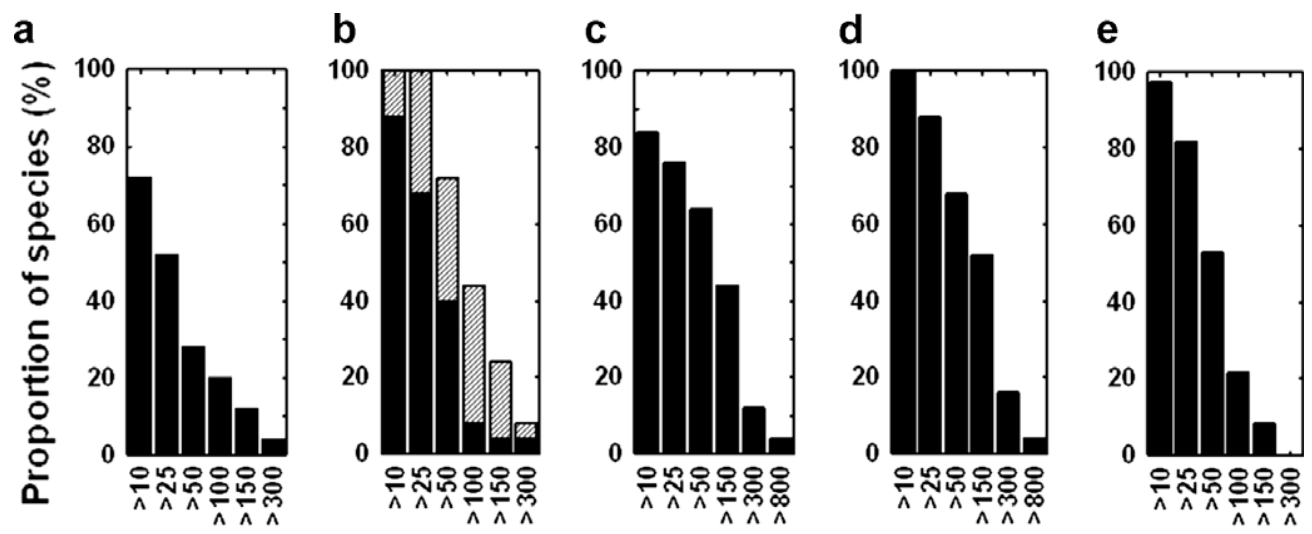

Range change (a-d: expansion and e: contraction) (\%)

Fig. 5 - Percentage range expansion for 25 indigenous ungulate species as a result of translocations in South Africa (a-d) and predicted range contraction for different taxa in South Africa as a result of predicted climate change (e). (a) Africa-wide extentof-occurrence (EOO) and extended EOO minimum convex polygons (MCPs), (b) South African quarter-degree grid-cell EOO (QDGC EOO) and extended QDGC EOO recorded outside the species EOO (solid bars) as well as inside the species EOO (hatched bars), (c) South African EOO MCPs and extended EOO MCPs, (d) historical EOO and extended EOO calculated using Alpha hulls $(\alpha=2)$, and (e) range contraction predicted as a result of predicted climate change for birds, mammals, reptiles, and invertebrates in South Africa according to Erasmus et al. (2002).

Table 1 - Generalized linear models (Poisson distribution, log-link function, correcting for over-dispersion) for propagule pressure. Best subset models were selected using Akaike information criterion (AIC) and Akaike weights ( $\left.w_{i}\right)$. The direction of relationship is in superscript for each predictor variable and non-significant relationships are indicated by NS. All maximum log likelihood ratio chi-square $\left(\chi^{2}\right)$ results were significant at $p<0.005$.

\begin{tabular}{llll} 
& AIC & $w_{\text {i }}$ & $\chi^{2}$ \\
\hline HUMAN POP $^{+}+$INDIG $^{\text {NS }}+$ INCOME $^{\text {NS }}$ & 3457 & 1.00 & 201 \\
HUMAN POP $^{+}+$INDIG $^{\text {NS }}$ & 3468 & 0.00 & 188 \\
HUMAN POP $^{+}+$INCOME $^{\text {NS }}$ & 3493 & 0.00 & 162 \\
\hline HUMAN POP: $\log _{10}$ human population, INDIG: indigenous ungulate species richness, and INCOME: $\log _{10}$ average annual income.
\end{tabular}



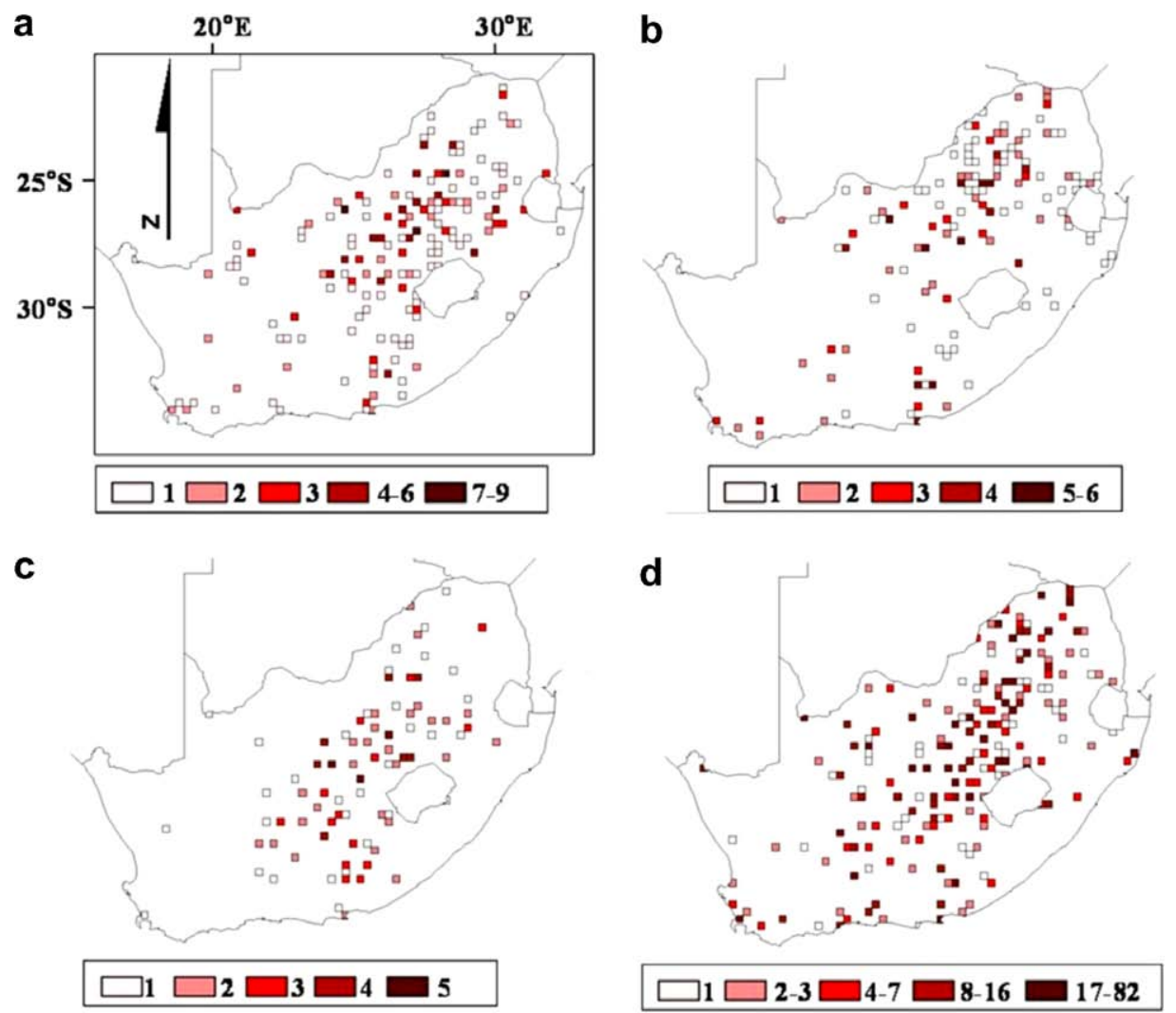

Fig. 6 - Areas of potential conservation concern in South Africa, in terms of (a) the presence of extraregional ungulates, (b) presence of potential hybrid ungulate pairs, (c) presence of ungulate genetic variants and hybrids, and (d) propagule pressure calculated from extralimital ungulate advertisements, 1996-2005 (maximum of 10 per extralimital ungulate per grid-cell).

country except the United States of America. Overall, the absence of a relationship between indigenous and introduced ungulate species richness suggests that, at least on a geopolitical basis at the global scale, the 'rich get richer' hypothesis (Stohlgren et al., 1999) does not apply to ungulate introductions. Nonetheless, the introduction of ungulates is fundamental to the process of invasion, and having been introduced these species are likely to establish and spread, given enough time (Forsyth et al., 2004; Jeschke and Strayer, 2005). Indeed, once extraregional ungulates have been introduced, the numbers of new introductions increase through space and time (Fig. 2), suggesting that more feral populations are likely to establish.

Several pathways for introductions clearly exist (Hulme et al., 2008), and in South Africa many extraregional ungulates on private farms or reserves appear to have originated from zoos (e.g. Ross, 1997). In some instances, non-indigenous ungulates such as Père David's deer (Elaphurus davidianus) and scimitar-horned oryx (Oryx dammah) originated from endangered species breeding centres in South Africa (see Brand, 1980). Sales of non-indigenous ungulates from zoos to private landowners are common for other countries (Spear and Chown, 2008), perhaps partly due to limited space in zoos (Lindburg, 1991; Lewandowski, 2003).

Introductions of non-indigenous species from zoos in South Africa are likely to have been subject to a formal permitting process, and will not necessarily lead to the establishment and spread of non-indigenous species. Moreover, where introduced ungulates have no substantive effect on indigenous species and ecosystems, the risks associated with sales to private landowners are likely to be low. Nonetheless, the release of non-indigenous species from ex situ conservation institutions may be cause for at least some concern. As zoos have served as a pathway for introductions in the past their effect could be similar to that of the aquarium and pet trades, where the introductions of fish (Rixon et al., 2005; Weigle et al., 2005), reptiles (Brown, 2006) and birds (Cassey et al., 2004) have led to invasions. In consequence, more attention needs to be given to relationships between the high value of zoos as facilities for ex situ conservation and for the education of the public regarding the value of biodiversity (both mandated by the Convention on Biological Diversity (CBD) - Articles 9 and 13 (United Nations, 1993)) and the risks of their contribution to activities of conservation concern that should be minimized (CBD Articles 6, 7, 10, and 14 (United Nations, 1993)).

Ungulate translocations in South Africa are not restricted to species from outside the country but include re-introductions of indigenous species and their translocation extralimitally, extending extents-of-occurrence of species. The fat tailed frequency distribution of ungulate translocations as shown by the permit application data not only indicates potential for a rapid rate of spread of ungulates (see Trakhtenbrot et al., 2005), but also considerable potential for genetic homogenization (see Olden et al., 2004). In particular, the maximum distance of translocation was comparable to dis- 
tances typically observed between significantly different populations of ungulates (e.g. Arctander et al., 1999; Lorenzen et al., 2006) and was further than long distance migrations undertaken by ungulates (Berger, 2004). Whether these translocations have resulted in introgression, or will do so in future, depends on the specific translocation and whether it spans boundaries of evolutionary significance such as major rifts, rivers or uplift areas (see Arctander et al., 1999; Pitra et al., 2002 for information on such boundaries in sable (Hippotragus niger) at the Africa-wide scale, and Moodley and Harley (2005) for mountain zebra (Equus zebra) in South Africa).

Having identified these risks, it should be noted that many early translocations (e.g. black rhinoceros (Diceros bicornis) from Kenya to the Addo Elephant park in the Eastern Cape of South Africa (Penzhorn, 1971) - excluded from Fig. 4), were undertaken to lessen the risk of extinction for entire species, and other considerations were given lower priority in the face of substantial threat to the species as a whole (Griffith et al., 1989). Modern conservation may be faced with similarly difficult decisions, but wherever possible consideration should be given to the extent to which translocations might cross boundaries of considerable evolutionary significance. Not only might such introductions result in the loss of amongpopulation diversity (see above and Storfer, 1999), but conservation actions are also only effective if they retain the potential for further evolutionary change in their target organisms and environments (Ashley et al., 2003; Pressey et al., 2003; Forest et al., 2007).

In addition to considerable translocation distances, we also found that areas with high human population densities are characterized by particularly high propagule pressure from extralimital species. However, propagule pressure was not related to either indigenous species richness or average annual income. Thus, it seems that the major reason for high propagule pressure in high human density areas may have more to do with the probability of the survival (and perhaps reproduction) of the animals (see also Chown et al., 2003; Evans et al., 2006), than with factors such as economics. These patterns of introduction may be self-reinforcing because high propagule pressure typically increases the likelihood that species will establish (Williamson, 1996; Forsyth and Duncan, 2001).

\subsection{Realized impacts}

As matters stand, the large increases in range sizes seen here are comparable with range alterations of c. $50 \%$ or more, calculated by Erasmus et al. (2002) for different taxa in South Africa, Meynecke (2004) for vertebrates in northern Queensland in Australia and Lawler et al. (2006) for mammals in the western hemisphere, as a result of predicted climate change. The estimates of range change in this study are also larger than range changes of less than $20 \%$ calculated by Harrison et al. (2006) for mammals in Europe and Thuiller et al. (2006) for mammals in Africa estimated as a result of predicted climate change. Whilst considerable concern has been voiced about the impacts of climate change on species range positions and sizes (e.g. Parmesan, 2006), it is clear that for ungulates the magnitude of range altera- tions precipitated by humans can be much larger than those that are predicted to take place as climates change. Obviously, climate change frequently leads to range size reductions (e.g. Erasmus et al., 2002; Thomas et al., 2004), which is not the case here. Moreover, the landscape context of range changes, owing to interactions among landscape alteration, introductions and climate change, is also very different because translocated individuals are moved to specific, often very favourable areas. It should also be recognized that direct human impacts and the influence of climate change may interact in ways that have not yet been sufficiently well explored.

Having identified the substantial translocation of ungulates to new areas, routes by which this might take place, and the potential for the development of conservation threats as a consequence of these translocations, the question remains of how much evidence exists to demonstrate that the potential threats are frequently realized. For South Africa, there is very little evidence. Lack of a demonstration of conservation problems caused by introductions does not mean that they do not exist. Indeed, elsewhere evidence for all of the above concerns has been recorded for ungulates (see Section 1). Moreover, there are good theoretical reasons to expect that such problems may arise (Gurevitch et al., 1992; Cunningham, 1996; Rhymer and Simberloff, 1996). Clearly, many areas in South Africa could be subject to substantial impacts, given the extent of propagule pressure and the fact that these areas have substantial numbers of indigenous ungulates. It might therefore be argued that a precautionary principle should be applied on the basis of work undertaken elsewhere and theoretical advances in conservation biology. However, without a greater body of evidence that the potential impacts of introductions are being realized, conservationists may be hard pressed to make a good case for limiting activities, such as ungulate introductions for trophy hunting and ecotourism purposes, which may result in substantial economic benefit.

\section{Acknowledgements}

We thank CapeNature for access to permit application data, the National Zoological Gardens of South Africa for access to the ISIS and Cang Hui for use of the program he wrote for the calculation of Alpha hulls. André Mader, Terry Robinson, and two anonymous referees are thanked for comments on a previous draft of the manuscript. Financial support was provided by the DST-NRF Centre of Excellence for Invasion Biology.

\section{Appendix A. Supplementary material}

Supplementary methods: the impacts of non-indigenous ungulates globally, the impacts of ungulate introductions in South Africa and the list of potential hybrid pairs.

Supplementary results: the impacts of non-indigenous ungulates globally and ungulate introductions in South Africa.

Fig. 1. Maps showing data used for calculating the extent of range change. 
Supplementary data associated with this article can be found, in the online version, at doi:10.1016/j.biocon.2008. 10.031 .

R E F E R E N C E S

Andrews, P., O’Brien, E.M., 2000. Climate, vegetation, and predictable gradients in mammal species richness in southern Africa. Journal of Zoology 251, 205-231.

Anonymous, 2004. National Environmental Management: Biodiversity Act. Government Gazette 467, 26436.

Arctander, P., Johansen, C., Coutellec-Vreto, M.-A., 1999. Phylogeography of three closely related African bovids (tribe Alcelaphini). Molecular Biology and Evolution 16, 1724-1739.

Ashley, M.V., Willson, M.F., Pergams, O.R.W., O’Dowd, D.J., Gende, S.M., Brown, J.S., 2003. Evolutionary enlightened management. Biological Conservation 111, 115-123.

Baccus, J.T., Harmel, D.E., Armstrong, W.E., 1985. Management of exotic deer in conjunction with white-tailed deer. In: Beasom, S.L., Roberson, S.F. (Eds.), Game Harvest Management. Caesar Kleberg Wildlife Research Institute, Kingsville, pp. 213-226.

Bayne, P., Harden, R., Davies, I., 2004. Feral goats (Capra hircus L.) in the Macleay river gorge system, north-eastern New South Wales, Australia. I. Impacts on soil erosion. Wildlife Research 31, 519-525.

Berger, J., 2004. The last mile: how to sustain long-distance migration in mammals. Conservation Biology 18, 320-331.

Beyer, H.L., 2004. Hawth's analysis tools for ArcGIS. <http:// www.spatialecology.com/htools> (accessed 25.08.06).

Bininda-Emonds, O.R.P., Cardillo, M., Jones, K.E., MacPhee, R.D.E., Beck, R.M.D., Grenyer, R., Price, S.A., Vos, R.A., Gittleman, J.L., Purvis, A., 2007. The delayed rise of present-day mammals. Nature 446, 507-512.

Bothma, J., du, P., 2005. It is time to end the debate on introducing exotic wildlife. South African Journal of Wildlife Research 35, 97-102.

Brand, D.J., 1980. Captive propagation at the national zoological gardens of South Africa, Pretoria. International Zoo Yearbook 20, 107-112.

Brooke, R.K., Lloyd, P.H., de Villiers, A.L., 1986. Alien and translocated terrestrial vertebrates in South Africa. In: Macdonald, I.A.W., Kruger, F.J., Ferrar, A.A. (Eds.), The Ecology and Management of Biological Invasions in Southern Africa. Oxford University Press, Cape Town, pp. 63-74.

Brown, R., 2006. Exotic pets invade United States ecosystems: legislative failure and a proposed solution. Indiana Law Journal 81, 713-731.

Burgman, M.A., Fox, J.C., 2003. Bias in species range estimates from minimum convex polygons: implications for conservation and options for improved planning. Animal Conservation 6, 19-28.

Butler, M.J., Teaschner, A.P., Ballard, W.B., McGee, B.K., 2005. Commentary: wildlife ranching in North America arguments, issues, and perspectives. Wildlife Society Bulletin 33, 381-389.

Cassey, P., Blackburn, T.M., Russell, G.J., Jones, K.E., Lockwood, J.L., 2004. Influences on the transport and establishment of exotic bird species: an analysis of the parrots (Psittaciformes) of the world. Global Change Biology 10, 417-426.

Castley, J.G., Boshoff, A.F., Kerley, G.I.H., 2001. Compromising South Africa's natural biodiversity - inappropriate herbivore introductions. South Africa Journal of Science 97, 344-348.

Chown, S.L., van Rensburg, B.J., Gaston, K.J., Rodrigues, A.S.L., van Jaarsveld, A.S., 2003. Energy, species richness, and human population size: conservation implications at a national scale. Ecological Applications 13, 1233-1241.

Conover, W.J., 1999. Practical Nonparametric Statistics. Wiley, New York.

Côté, S.D., 2005. Extirpation of a large black bear population by introduced white-tailed deer. Conservation Biology 19, 16681671.

Cunningham, A.A., 1996. Disease risks of wildlife translocations. Conservation Biology 10, 349-353.

Dale, P., 2005. Introduction to Mathematical Techniques Used in GIS. CRC Press, Boca Raton.

Dolman, P.M., Wäber, K., 2008. Ecosystem and competition impacts of introduced deer. Wildlife Research 35, 202-214.

Donlan, J., 2005. Re-wilding North America. Nature 436, 913-914.

Dryden, G.M., Craig-Smith, S.J., 2004. Safari Hunting of Australian Exotic Wild Game. Rural Industries Research and Development Corporation, Barton.

Erasmus, B.F.N., van Jaarsveld, A.S., Chown, S.L., Kshatriya, M., Wessels, K.J., 2002. Vulnerability of South African animal taxa to climate change. Global Change Biology 8, 679-693.

Evans, K.L., Warren, P.H., Gaston, K.J., 2004. Species-energy relationships at the macroecological scale: a review of the mechanisms. Biological Reviews 79, 1-25.

Evans, K.L., van Rensburg, B.J., Gaston, K.J., Chown, S.L., 2006. People, species richness and human population growth. Global Ecology and Biogeography 15, 625-636.

Forest, F., Grenyer, R., Rouget, M., Davies, T.J., Cowling, R.M., Faith, D.P., Balmford, A., Manning, J.C., Procheş, Ş., van der Bank, M., Reeves, G., Hedderson, T.A.J., Savolainen, V., 2007. Preserving the evolutionary potential of floras in biodiversity hotspots. Nature 445, 757-760.

Forsyth, D.M., Duncan, R.P., 2001. Propagule size and the relative success of exotic ungulate and bird introductions to New Zealand. American Naturalist 157, 583-595.

Forsyth, D.M., Duncan, R.P., Bomford, M., Moore, G., 2004. Climatic suitability, life-history traits, introduction effort, and the establishment and spread of introduced mammals in Australia. Conservation Biology 18, 557-569.

Gaston, K.J., 1990. Patterns in the geographical ranges of species. Biological Reviews 65, 105-129.

Gaston, K.J., Blackburn, T.M., 1999. A critique for macroecology. Oikos 84, 353-368.

Goodman, S.J., Barton, N.H., Swanson, G., Abernethy, K., Pemberton, J.M., 1999. Introgression through rare hybridisation: a genetic study of a hybrid zone between red and sika deer (Genus Cervus) in Argyll, Scotland. Genetics 152, 355-371.

Griffith, B., Scott, J.M., Carpenter, J.W., Reed, C., 1989. Translocation as a species conservation tool: status and strategy. Science 245, 477-480.

Gurevitch, J., Morrow, L.L., Wallace, A., Walsh, J.S., 1992. A metaanalysis of competition in field experiments. American Naturalist 140, 539-572.

Harrison, P.A., Berry, P.M., Butt, N., New, M., 2006. Modelling climate change impacts on species' distributions at the European scale: implications for conservation policy. Environmental Science and Policy 9, 116-128.

Hoegh-Guldeberg, O., Hughes, L., McIntyre, S., Lindenmayer, D.B., Parmesan, C., Possingham, H.P., Thomas, C.D., 2008 Assisted colonization and rapid climate change. Science 321, 345-346.

Hofer, D., 2002. The lion's share of the hunt: trophy hunting and conservation: a review of the legal Eurasian tourist hunting market and trophy trade under CITIES. TRAFFIC Europe regional report. TRAFFIC Europe, Brussels.

Hulme, P.E., Bacher, S., Kenis, M., Klotz, S., Kühn, I., Minchin, D., Nentwig, W., Olenin, S., Panov, V., Pergl, J., Pyšek, P., Roques, A., Sol, D., Solarz, W., Vila, M., 2008. Grasping at the routes of 
biological invasions: a framework for integrating pathways into policy. Journal of Applied Ecology 45, 403-414.

ISIS, 2007. International species information system. <http:// www.isis.org> (accessed 12.02.07).

Jeschke, J.M., Strayer, D.L., 2005. Invasion success of vertebrates in Europe and North America. Proceedings of the National Academy of Sciences of the United States of America 102, 7198-7202.

Johnson, J.B., Omland, K.S., 2004. Model selection in ecology and evolution. Trends in Ecology and Evolution 19, 101-108.

Keith, M., 2004. Geographic information system (GIS) data of South African mammal taxa. University of Pretoria, Pretoria, South Africa. <http://zoology.up.ac.za/samammals/> (accessed 06.04.06).

Lawler, J.L., White, D., Neilson, R.P., Blaustein, A.R., 2006. Predicted climate-induced range shifts: model differences and model reliability. Global Change Biology 12, 1568-1584.

Lever, C., 1985. Naturalized Mammals of the World. Longman, London.

Lewandowski, A.H., 2003. Surplus animals: the price of success. Journal of the American Veterinary Medical Association 223, 981-983.

Lindburg, D.G., 1991. Zoos and the "surplus" problem. Zoo Biology 10, 1-2.

Lindsey, P.A., Alexander, R., Frank, L.G., Mathieson, A., Romañach, S.S., 2006. Potential of trophy hunting to create incentives for wildlife conservation in Africa where alternative wildlifebased land uses may not be viable. Animal Conservation 9, 283-291.

Lloyd, P.H., Millar, J.C.G., 1983. A questionnaire survey (1969-1974) of some of the larger mammals of the Cape Province. Bontebok 3, 1-49.

Lockwood, J.L., Cassey, P., Blackburn, T., 2005. The role of propagule pressure in explaining species invasions. Trends in Ecology and Evolution 20, 223-228.

Long, J.L., 2003. Introduced Mammals of the World: Their History, Distribution, and Influence. Collingwood, CSIRO publishing, Australia.

Lorenzen, E.D., Arctander, P., Siegismund, H.R., 2006. Regional genetic structuring and evolutionary history of the impala Aepyceros melampus. Journal of Heredity 97, 119-132.

Loveridge, A.K., Reynolds, J.C., Milner-Gulland, E.J., 2006. Does sport hunting benefit conservation? In: Mac Donald, D., Service, K. (Eds.), Key Topics in Conservation. Blackwell Publishers, Oxford, pp. 222-238.

Lowe, S., Browne, M., Boudjelas, S., De Poorter, M., 2000. 100 of the world's worst invasive species: a selection from the global invasive species database. The Invasive Species Specialist Group (ISSG) a specialist group of the Species Survival Commission (SSC) of the World Conservation Union (IUCN), Auckland.

Mandal, D.P., Murthy, C.A., 1997. Selection of alpha for alpha-hull in $R^{2}$. Pattern Recognition 30, 1759-1767.

Meltzer, D.G.A., 1993. Historical survey of disease problems in wildlife populations - southern Africa mammals. Journal of Zoo and Wildlife Medicine 24, 237-244.

Meynecke, J-O., 2004. Effects of global climate change on geographic distributions of vertebrates in North Queensland. Ecological Modelling 174, 347-357.

Moodley, Y., Harley, E.H., 2005. Population structuring in mountain zebras (Equus zebra): the molecular consequences of divergent demographic histories. Conservation Genetics 6, 953-968.

Moritz, C., 1999. Conservation units and translocations: strategies for conserving evolutionary processes. Hereditas 130, 217-228.

Mungall, E.C., Sheffield, W.J., 1994. Exotics on the Range: the Texas Example. Texas A\&M University Press, College Station, Texas.
Oden, N.L., 1984. Assessing the significance of a spatial correlogram. Geographical Analysis 16, 1-16.

Olden, J.D., Poff, N.L., Douglas, M.R., Douglas, M.E., Fausch, K.D., 2004. Ecological and evolutionary consequences of biotic homogenization. Trends in Ecology and Evolution 19, 18-23.

Parmesan, C., 2006. Ecological and evolutionary responses to recent climate change. Annual Review of Ecology, Evolution and Systematics 37, 637-669.

Parr, C.L., Chown, S.L., 2003. Burning issues for conservation: a critique of faunal fire research in southern Africa. Austral Ecology 28, 382-395.

Penzhorn, B.L., 1971. A summary of the re-introduction of ungulates into South African National Parks (to 31 December 1970). Koedoe 14, 145-159.

Pitra, C., Hansen, A.J., Lieckfeld, D., Arctander, P., 2002. An exceptional case of historical outbreeding in African sable antelope populations. Molecular Ecology 11, 1197-1208.

Pressey, R.L., Cowling, R.M., Rouget, M., 2003. Formulating conservation targets for biodiversity pattern and process in the Cape Floristic region, South Africa. Biological Conservation 112, 99-127.

Rhymer, J.M., Simberloff, D., 1996. Extinction by hybridisation and introgression. Annual Review of Ecology and Systematics 27, 83-109.

Rixon, C.A.M., Duggan, I.C., Bergeron, N.M.N., Ricciardi, A., MacIsaac, H.J., 2005. Invasion risks posed by the aquarium trade and live fish markets on the Laurentian Great Lakes. Biodiversity and Conservation 14, 1365-1381.

Rondinini, C., Wilson, K.A., Boitani, L., Grantham, H., Possingham, H.P., 2006. Tradeoffs of different types of species occurrence data for use in systematic conservation planning. Ecology Letters 9, 1136-1145.

Ross, N., 1997. Notes on the natural history, capturing and hunting of the Kafue lechwe in the Eastern Cape. Pelea 16, 5-8.

Rubenstein, D.R., Rubenstein, D.I., Sherman, P.W., Gavin, T.A., 2006. Pleistocene park: does re-wilding North America represent sound conservation for the 21st century? Biological Conservation 132, 232-238.

Siegfried, W.R., 1962. Introduced vertebrates in the Cape Province. Cape Department of Nature Conservation Annual Report 19, pp. 80-87.

Skinner, J.D., Chimimba, C.T., 2005. The Mammals of the Southern African Subregion, third ed. Cambridge University Press, London.

Spear, D., Chown, S.L., 2008. Taxonomic homogenization in ungulates: patterns and mechanisms at local and global scales. Journal of Biogeography 35, 1962-1975.

Statistics South Africa, 1996. Population census, 1996. <http:// www.statssa.gov.za> (accessed 10.04.06).

Statistics South Africa, 2001. Personal income data, 2001. <http:// www.statssa.gov.za> (accessed 06.04.06).

Stohlgren, T.J., Binkley, D., Chong, G.W., Kalkhan, M.A., Schell, L.D., Bull, K.A., Otsuki, Y., Newman, G., Bashkin, M., Son, Y., 1999. Exotic plant species invade hotspots of native plant diversity. Ecological Monographs 69, 25-46.

Storfer, A., 1999. Gene flow and endangered species translocations: a topic revisited. Biological Conservation 87, 173-180.

Thomas, C.D., Cameron, A., Green, R.E., Bakkenes, M., Beaumont, L.J., Collingham, Y.C., Erasmus, B.F.N., de Siqueira, M.F., Grainger, A., Hannah, L., Hughes, L., Huntley, B., van Jaarsveld, A.S., Midgley, G.F., Miles, L., Ortega-Huerta, M.A., Peterson, A.T., Phillips, O.L., Williams, S.E., 2004. Extinction risk from climate change. Nature 427, 145-148.

Thuiller, W., Broennimann, O., Hughes, G., Alkemade, J.R.M., Midgley, G.F., Corsi, F., 2006. Vulnerability of African mammals to anthropogenic climate change under conservative land transformation assumptions. Global Change Biology 12, 424-440. 
Trakhtenbrot, A., Nathan, R., Perry, G., Richardson, D., 2005. The importance of long-distance dispersal in biodiversity conservation. Diversity and Distributions 11, 173-181.

United Nations, 1993. Convention on biological diversity (with annexes). Concluded at Rio de Janeiro on 5 June 1992. United Nations Treaty Series, 1760, 30619. <http://69.90.183.227> (accessed 22.02.08).

Wagner, J.-O., 2002. Gen2Shp. <http://www.intevation.de/ jan/ gen2shp> (accessed 15.08.06).

Wardle, D.A., Barker, G.M., Yeates, G.W., Bonner, K.I., Ghani, A., 2001. Introduced browsing mammals in New Zealand natural forests: aboveground and belowground consequences. Ecological Monographs 71, 587-614.

Weigle, S.M., Smith, L.D., Carlton, J.T., Pederson, J., 2005. Assessing the risk of introducing exotic species via the live marine species trade. Conservation Biology 19, 213-223.

Williamson, M., 1996. Biological Invasions. Chapman and Hall, London.

Wilson, D.E., Reeder, D.M., 2005. Mammal Species of the World, third ed. The John Hopkins University Press, Baltimore.

Zimov, S.A., 2005. Pleistocene park: return of the mammoth's ecosystem. Science 308, 796-798. 